\title{
Tesis
}

\section{Estudio exploratorio sobre la efectividad de un sistema ergonómico contra el desorden músculo-esqueletal ocasio- nado por las funciones repetitivas de los trabajos de oficina}

\author{
Rosamar Vega Cidraz
}

\section{Síntesis}

Esta investigación tiene el propósito de explorar el tema de la efectividad de la implantación de un sistema ergonómico contra el desorden músculo-esqueletal ocasionado por las funciones repetitivas de los trabajos de oficina. La hipótesis de este estudio está enfocada en que los padecimientos de este tipo de desorden se reducen cuando se aplican medidas ergonómicas eficientes.

En este trabajo se presentan las distintas leyes y regulaciones federales y locales relevantes a este asunto, cuyos objetivos son minimizar los riesgos a la seguridad y salud en el lugar de trabajo. Además, se discuten estadísticas y estudios de expertos en este tema. Uno de los planteamientos es que hacer ejercicios de estiramiento con aquellos músculos sujetos a constantes movimientos, reduce el padecimiento de una condición muscular o esqueletal. Otro planteamiento que llama la atención es, que tomar periodos de descanso fraccionados dentro de la jornada de trabajo diaria, adicional al periodo de ingerir alimentos, ayuda a minimizar dicho padecimiento.

Para corroborar la veracidad de la hipótesis y de los distintos planteamientos y teorías sobre el tema, se realizó un estudio exploratorio en un banco comercial en Puerto Rico. Los hallazgos de este estudio revelan que, el hecho de que un patrono provea equipos 
ergonómicos a sus empleados, no reduce necesariamente el padecimiento de desorden músculo-esqueletal. Otro dato importante es que el padecimiento de dicho desorden afecta la productividad laboral de los que la padecen, en mayor o menor grado. Como parte de este trabajo, se proveen recomendaciones que pudieran aliviar este problema.

\title{
El Tratado de Libre Comercio de América del Norte (TLCAN) 10 años después
}

\author{
José Ramiro Mora Rizo
}

\section{Síntesis}

En esta tesis se presentan dos temas que generan intensos debates en la sociedad mundial, éstos son la globalización y la integración. El propósito es ubicar al lector en el contexto correcto para que se familiarice mejor con el objetivo de este trabajo que es presentar y analizar los datos y las estadísticas existentes en relación con el Tratado de Libre Comercio de América del Norte (TLCAN), y con los efectos que ha tenido en México.

Se abordan temas que van desde el marco jurídico de los tratados internacionales en México, hasta el desempeño de la industria maquiladora de exportación desde que se firmó el TLCAN. Se hace hincapié en un análisis de los movimientos de exportación e importación mexicanos, su composición, desarrollo y saldo de la balanza comercial y la inversión extranjera en México, además de datos sobresalientes acerca del desempeño de los empleados y los salarios.

Cabe mencionar que la investigación realizada se basó, casi en su totalidad, en la revisión de la bibliografía pertinente en documentos y en la inmensa cantidad de información en la Internet. 


\title{
E-Commerce and Its Taxation Impasse in the USA
}

\author{
Sonimar Pérez Echevarría
}

\begin{abstract}
The increase in commercial transactions by electronic means or e-commerce has increased the concern regarding its tax treatment. State Governments claim that they are losing lots of money that should be destined to education, health, and other benefits for their communities, due to the tax-free treatment of the internet. Thus, it is proposed to levy a tax on e-transactions and encourage governments to simplify the sales tax system to make this viable for all states and companies. Others maintain, that e-losses haven't been that great and that taxation could jeopardize the intern's usage growth and consequently therefore the USA economy, thus advocating against possible e-taxes. This study presents a brief history of the electronic commerce; explain the basics of the USA sales tax system and its corresponding laws. It shows the different points of view regarding the subject and propositions brought up by the different groups involved, including, states, companies and the government.
\end{abstract}

